\title{
Viral Load, Antibody Titers and Recombinant Open Reading Frame 2 Protein-Induced Th1/Th2 Cytokines and Cellular Immune Responses in Self-Limiting and Fulminant Hepatitis $E$
}

\author{
S. Saravanabalaji ${ }^{a} \quad$ A.S. Tripathy ${ }^{a} \quad$ R.R. Dhoot ${ }^{b} \quad$ M.S. Chadha ${ }^{a}$ A.L. Kakrani ${ }^{b}$ \\ V.A. Arankalle ${ }^{a}$ \\ ${ }^{a}$ Hepatitis Group, National Institute of Virology, and ${ }^{\text {b}}$ Department of Medicine, BJ Medical College, Pune, India
}

\section{Key Words}

Hepatitis E virus · Viral load · Cytokines · Antibody titers
Conclusion: The results document increased Th1/Th2 responses and anti-HEV titers in FHF patients that warrant indepth immunological studies. Copyright $\odot 2009$ S. Karger AG, Basel

\section{Introduction}

Hepatitis E virus (HEV) represents the major cause of water-borne epidemics in India and sporadic acute viral hepatitis among adults (AVH) [1,2]. High mortality among pregnant women is the characteristic feature of hepatitis E epidemics [3, 4]. Among sporadic patients with fulminant hepatic failure (FHF), 37-62\% of adult patients are related to HEV infection [5-7]. Exposure of susceptible individuals to HEV can lead to: (1) subclinical infection, (2) self-limiting clinical hepatitis, and (3) FHF. The basis of differential outcome of HEV infection is not well understood. FHF is one of the most challenging and life-threatening syndromes in clinical medicine and is characterized by massive hepatocellular necrosis and encephalopathy [8]. The etiology of FHF varies greatly worldwide. In developed countries like the United States and UK, the most common cause of FHF is drug-induced liver injury (most commonly acetaminophen toxicity) [9,

\section{KARGER}

Fax +4161306 1234 E-Mail karger@karger.ch www.karger.com

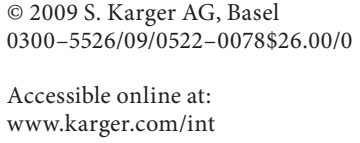

Dr. V.A. Arankalle

Hepatitis Group, National Institute of Virology

130/1, Sus Road, Pashan

Pune, Maharashtra 411021 (India)

Tel. +91 202588 0982, Fax +91 202587 1895, E-Mail varankalle@yahoo.com 
10]. Both host and viral factors are associated with outcome of various infections. This preliminary study attempts to assess humoral and cellular responses as well as viral load in individuals with self-limiting hepatitis $\mathrm{E}$ and those progressing to FHF to help recognizing mechanisms associated with the development of FHF. The possibility of identifying prognostic markers for progression to FHF was another objective.

\section{Materials and Methods}

The study protocol was approved by the Human Ethical committee of the BJ Medical College and Sasoon General Hospital, Pune, Maharashtra.

\section{Study Population}

The patients were classified as AVH or FHF based on standard clinical and biochemical criteria $[6,11]$. The diagnosis of hepatitis E was based on the presence of IgM antibodies to HEV (anti-HEV IgM). A study population of 78 (36 males, 12 females) was divided into three groups: (1) AVH group, consisting of 48 acute hepatitis E patients with uneventful recovery, (2) FHF group, comprising 14 hepatitis E patients progressing to fulminant hepatic failure, and (3) control group, including 16 apparently healthy adults negative for both IgM and IgG antibodies to HEV. Based on the outcome of the disease, the FHF patients were further classified as either fatal $(n=6)$ or recovered $(n=8)$. The patients as well as controls were enrolled during October 2003-September 2006 from the state of Maharashtra, Western India. FHF was defined when a patient with no history of liver disease developed encephalopathy within 8 weeks of onset of jaundice [11]. Written informed consent was obtained in each subject.

Sixteen of the $48 \mathrm{AVH}$ patients consented for follow-up. For the first sampling $(n=16)$, mean post-onset day of clinical symptoms (POD), i.e. number of days after the onset of clinical symptoms on which the sample was collected, was $13.75 \pm 1.77$ days. Subsequently, three sequential samples were collected at 14,16 , and 20 days' interval ( $n=16,15$ and 10 , respectively). Of the 14 FHF patients admitted to the Medicine wards at Sasoon Hospital, Pune, 13 could be followed up daily or on alternate days. The first blood sample was collected within $48 \mathrm{~h}$ of onset of hepatic encephalopathy ( $\mathrm{n}=14$; mean POD: $9.93 \pm 1.57$ days). The last sample was collected after the patient had recovered from hepatic encephalopathy (recovered group) $(n=7$; mean POD: $13.57 \pm 1.30$ days). In the fatal group, the last sample was obtained within $24 \mathrm{~h}$ of the patient's death (mean POD, $16.50 \pm 1.42$ days).

\section{Serology}

Blood samples were collected in K3 EDTA and plasma was separated within $4 \mathrm{~h}$ of collection. All samples were screened in ELISA for the presence of, IgM antibodies against hepatitis A virus (anti-HAV IgM; Hepavase A-96, General Biologicals Corp., Taiwan), hepatitis B surface antigen (HBsAg; Surase B-96, General Biologicals), IgM antibodies to hepatitis $\mathrm{B}$ core antigen (anti$\mathrm{HBc}$ IgM; Anticorase B-96, General Biologicals), antibodies to hepatitis C (anti-HCV; Ortho HCV 3.0, Ortho Clinical Diagnostics, USA), anti-HEV IgM and IgG employing recombinant ORF2 protein (rORF2p) [12] and serum alanine amino transferase levels (ALT; Span Diagnostics, India). Titers of anti-HEV IgM and IgG were determined by subjecting two-fold serum/plasma dilutions to ELISA protocols. All specimens from FHF cases were tested for HBV DNA [13] and HCV RNA [14].

\section{TaqMan-Based One-Step Real-Time RT-PCR}

HEV-RNA load (copies/ml) was determined by Taqman RTPCR using primers and probe corresponding to HEV ORF1 (7300 Real Time PCR system, Applied Biosystems, Foster City, Calif., USA) according to the protocol described earlier [15]. Briefly, a 1,067-bp fragment of HEV genome (4,632-5,698 nt) was PCR amplified and cloned into pGEM-T Easy vector (Promega, Madison, Wisc., USA). Plasmid was linearised and in vitro transcription was done using T7 Riboprobe In Vitro Transcription System (Promega). Standard curve showed linear relationship $\left(\mathrm{r}^{2}=0.99\right)$ from 10 to $10^{10} \mathrm{RNA}$ copies/reaction. The sensitivity of the assay was 100 copies/ml. HEV RNA was extracted from samples using QIAamp viral RNA mini kit (Qiagen, Hilden, Germany) and used. Every sample (plasma/serum) collected from AVH and FHF categories of patients were screened for the detection/quantitation of HEV RNA.

Stimulation of PBMCs and Cytokine Assay

Cytokine assay was carried out as previously described [16]. Briefly, peripheral blood mononuclear cells (PBMCs) were isolated, washed and resuspended in RPMI 1640 (Invitrogen, Carlsbad, Calif., USA) supplemented with $10 \%$ heat-inactivated fetal calf serum (Invitrogen). PBMCs at a concentration of $2 \times 10^{6}$ cells/well were set up in 6-well plate (Nunc, Denmark). Cells were stimulated with HPLC purified rORF2p from genotype-1 HEV [17]. Supernatants from cultured cells were harvested after $72 \mathrm{~h}$ and stored at $-70^{\circ}$. Levels of IFN- $\gamma$, IL-2, IL-12, TNF- $\alpha$, IL-10 and IL-4 were measured from the stored cell supernatants by ELISA (ELISA SETS, BD Pharmingen, San Diego, Calif., USA), in accordance with the manufacturer's instructions. The sensitivity of ELISA SET used was $31.3 \mathrm{pg} / \mathrm{ml}$ for IL-12 and $4.7 \mathrm{pg} / \mathrm{ml}$ for IFN- $\gamma$ and TNF- $\alpha$ and $7.8 \mathrm{pg} / \mathrm{ml}$ for IL-2, IL-10, and IL-4, respectively.

\section{Lymphocyte Proliferation Assay}

Lymphocyte proliferation assay (LPA) was carried out as previously described [17]. Briefly, $1 \times 10^{5}$ cells/well PBMCs were cultured quadriplicately in 96-well flat bottom plate (Nunc, Denmark) at $37^{\circ}$ with $5 \% \mathrm{CO}_{2}$. Cells cultured with media and with PHA $(5 \mu \mathrm{g} / \mathrm{ml}$ ) (Sigma, USA) served as controls. $20 \mu \mathrm{g} / \mathrm{ml}$ of rORF2p was used as recall antigen. The optimum doses of PHA and rORF2 $p$ were decided based on previous dose response studies. On the 5th day of culture, the cells were pulsed with $1 \mu \mathrm{Ci}$ of tritiated thymidine (BARC, Mumbai, India) for $24 \mathrm{~h}$. Cells were harvested onto GF/C filter (Whatman, UK) membrane and counts taken on a $\beta$-counter (LKB Pharmacia, Sweden) using standard protocol. Data for each sample was expressed as stimulation index (SI), calculated as the ratio between mean counts per minute (cpm) obtained in the presence and absence of the antigen. Samples showing SI values $\geq 3$ were considered responders. The laboratory is approved as radioisotope laboratory by Atomic Energy Regulatory Board, Radiological Safety Division, Government of India. 
Table 1. Clinical and demographic profile of FHF patients

\begin{tabular}{|c|c|c|c|}
\hline Parameters & Recovered & Fatal & Total \\
\hline Number (\%) & $8(57.14)$ & $6(42.86)$ & 14 \\
\hline \multicolumn{4}{|l|}{ Age } \\
\hline Mean $\pm \mathrm{SE}$ & $26.4 \pm 1.64$ & $25.5 \pm 0.94$ & $26 \pm 1.39$ \\
\hline Range & $19-45$ & $23-35$ & $19-45$ \\
\hline $\mathrm{M}: \mathrm{F}$ & $3: 5$ & $2: 4$ & $5: 9$ \\
\hline \multicolumn{4}{|c|}{ Pregnancy:nonpregnancy } \\
\hline (female, $\mathrm{n}=9$ ) & $3: 2$ & $4: 0$ & $7: 2$ \\
\hline \multicolumn{4}{|c|}{ Jaundice-encephalopathy interval, days } \\
\hline Mean $\pm \mathrm{SE}$ & $7.5 \pm 1.1$ & $13.17 \pm 1.42$ & $9.93 \pm 1.57$ \\
\hline Range & $3-13$ & $7-20$ & $3-20$ \\
\hline \multicolumn{4}{|c|}{ Jaundice-encephalopathy interval, \% } \\
\hline$\leq 2$ weeks & $8(72.7)$ & $3(27.3)$ & $11(78.6)$ \\
\hline$>2$ weeks & nil & $3(100)$ & $3(21.4)$ \\
\hline
\end{tabular}

\section{Statistical Analysis}

Inter- and intragroup comparisons were made by the MannWhitney and Willcoxon signed-rank tests. The $\chi^{2}$ test and Fisher's exact test were used to compare frequencies. The statistical software SPSS 11.0 was used for statistical analyses. The values for POD of sample collection, age in years and cytokine levels (pico$\mathrm{gram} / \mathrm{ml}$ ) are expressed as mean $\pm \mathrm{SE}$.

\section{Results}

\section{Study Subjects}

The patient group included only anti-HEV IgM positives. Thus, all the patients were negative for anti-HAV IgM, anti-HBc IgM and HBsAg. One HBsAg carrier with superimposed $\mathrm{HEV}$ infection was excluded from analysis (AVH category), the total number for analysis being 47. The control group subjects were negative for hepatitis viral markers of recent infection as well as HBsAg, anti$\mathrm{HCV}$ and anti-HEV IgG antibodies. Acute HEV infection was recorded more frequently among males than females ( $\mathrm{n}=35,74.47 \%$ vs. $\mathrm{n}=12,25.53 \%, \mathrm{p}=0.000)$. The mean age was $27.09 \pm 1.45$ years. Of the 14 FHF patients, 5 were males and 9 were females; male to female ratio was 1:1.8. All the $14 \mathrm{FHF}$ patients were negative for HBV DNA and HCV RNA.

Table 1 provides details of the FHF group. Overall case fatality rate (CFR) in this group was $42.86 \%(6 / 14)$. The mean age of FHF patients with fatal outcome $(n=6 ; 25.5$ \pm 0.94 years) was similar to that of surviving patients ( $\mathrm{n}=8 ; 26.4 \pm 1.64$ years). Of the 14 FHF cases, 7 were pregnant women $(7 / 14,50 \%)$. The mortality rate was higher among pregnant $(4 / 7,57.14 \%)$ than non-pregnant women $(0 / 2)$. During the third trimester of pregnancy, very high $(4 / 5,80 \%)$ mortality was recorded. Importantly, 2/5 male FHF patients succumbed to the disease. The CFRs were $27.3 \%$ (3/11) and 100\% (3/3), respectively, when the interval between the onset of jaundice and encephalopathy development was $\leq 2$ and $>2$ weeks.

\section{Viral Load}

The first plasma sample collected from $47 \mathrm{AVH}$ (mean POD, $12.84 \pm 1.99$ days) and 14 FHF patients (mean POD, $9.93 \pm 1.57$ days) were subjected to quantitation of HEV RNA by real-time RT-PCR. HEV RNA was detected in 22 of $47(46.81 \%) \mathrm{AVH}$ patients and the mean copy number was $2.4 \times 10^{4} \pm 1.92 \times 10^{4}$ copies $/ \mathrm{ml}$ of plasma. Interestingly, HEV RNA could be detected only in one pregnant FHF patient with fatal outcome (1/14, 7.14\%) $\left(4.17 \times 10^{3}\right.$ copies $/ \mathrm{ml}$ of plasma). No viral RNA could be detected in the follow-up samples of both AVH and FHF group patients.

\section{Antibody Profiles}

Anti-HEV IgM titer was observed earlier to be a function of time of sample collection after the onset of jaundice [1]. Therefore, for the comparison of titers, based on the post-onset week of collection of blood after the appearance of clinical symptoms, AVH and FHF patients were divided into two categories: $<2$ weeks and $2-4$ weeks. Among FHF patients bled within two weeks, both anti-HEV IgM and IgG titers were significantly higher than the AVH group ( $p=0.000$ and $p=0.012$, respectively) (fig. 1). Only IgM titers were significantly higher $(p=0.01)$ when samples obtained after $>2$ weeks were compared.

\section{Th1/ Th2 Cytokines}

$\mathrm{AVH}$ and Controls

Only IL-12 was significantly elevated in the AVH group when compared with the controls $(\mathrm{p}=0.011)$. Though statistically insignificant, IFN- $\gamma$ levels in patients with AVH were 10.77 times higher than healthy controls $(58.46 \pm 19.55$ vs. $5.43 \pm 3.48$ pg/ml) (fig. 2). TNF- $\alpha$ and IL-2 levels were similar in AVH and control groups. No significant difference was found between AVH and control subjects for IL-10 (fig. 2) and IL-4 (AVH: $3.68 \pm 0.86 \mathrm{pg} / \mathrm{ml}$, control: undetectable).

\section{$\mathrm{AVH}$ and FHF}

Production of IFN- $\gamma$, IL-2 and TNF- $\alpha$ were significantly higher in patients with FHF than in those with $\mathrm{AVH}(\mathrm{p}=0.017, \mathrm{p}=0.002$ and $\mathrm{p}=0.000$, respectively) 
Fig. 1. Geometric mean titers (GMT) of anti-HEV IgM and IgG antibodies in AVH and FHF patients: a within 2 weeks, b 2-4 weeks after the onset of clinical symptoms. NS = Nonsignificant.
Fig. 2. Production of IFN- $\gamma$, IL-2, IL-12, TNF- $\alpha$ and IL-10 by PBMCs of AVH patients (mean POD, $12.84 \pm 1.99$ days) and controls in response to stimulation with rORF2p. Values indicate mean \pm SE pg/ ml. NS $=$ Nonsignificant.
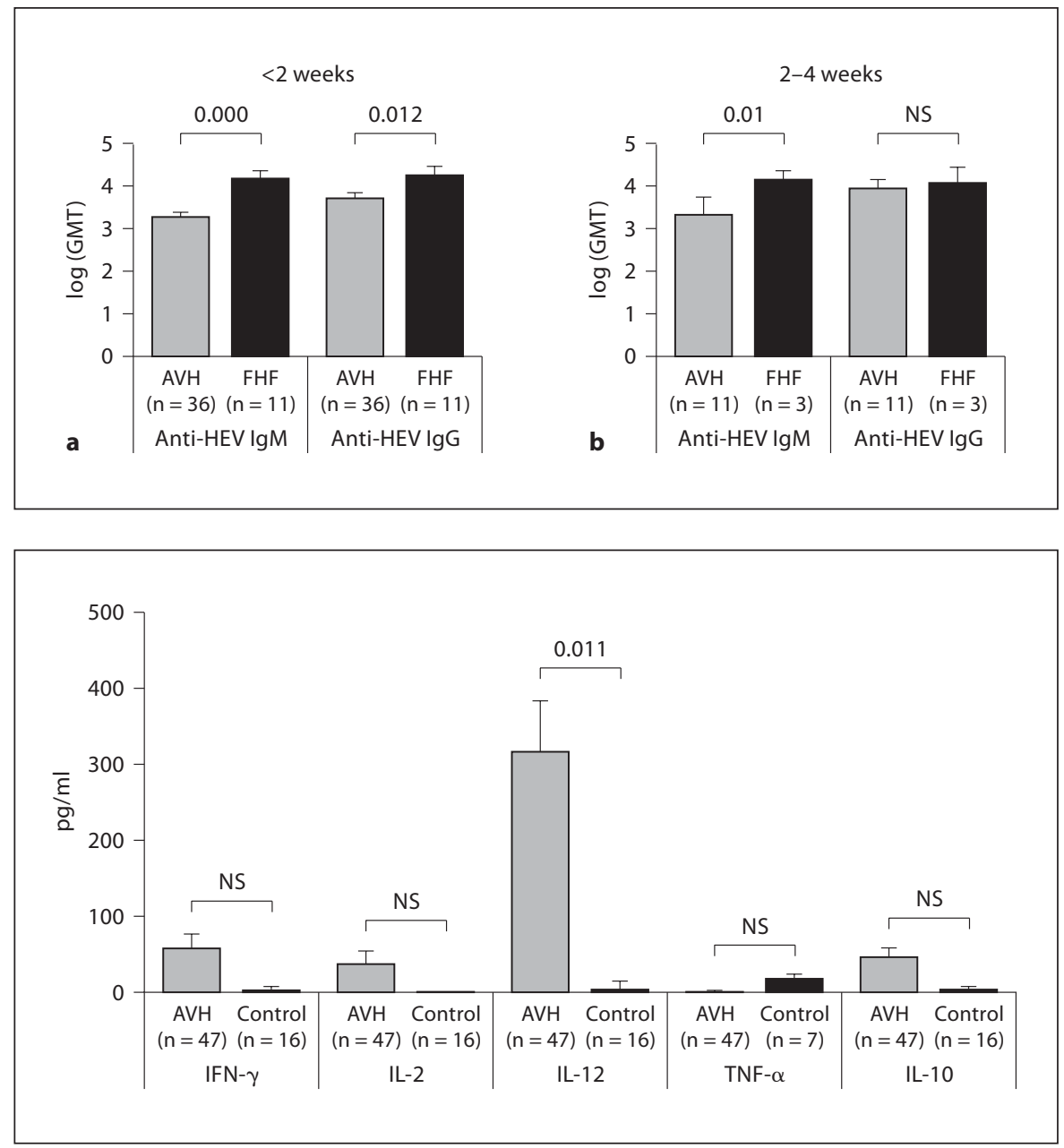

e(fig. 3). IL-12 levels in AVH and FHF patients were comparable $(\mathrm{p}>0.05)$. IL-10 levels were significantly higher in FHF than AVH group ( $\mathrm{p}=0.008)$. IL-4 levels between FHF and AVH groups were comparable $(1.0 \pm 0.95$ and $3.68 \pm 0.86 \mathrm{pg} / \mathrm{ml}$, respectively). Serum ALT levels were significantly higher in FHF patients $(\mathrm{p}=0.000)$ (fig. 3).

Analysis of the sequential samples collected from AVH patients documented that IL-12 levels at the first sampling ( $\mathrm{n}=16$, mean POD: $13.75 \pm 1.77$ days) were significantly higher compared to controls $(\mathrm{p}=0.011)$ (fig. 4). At the time of the second sampling $(\mathrm{n}=16$, mean POD: $27.75 \pm 1.77$ days), IFN- $\gamma$ levels rose to significant levels $(\mathrm{p}=0.005)$ when compared to the first sample (fig. 4). At this time, the IL-12 levels returned to normal. IL-12 and IFN- $\gamma$ levels were below the detection limits at the third ( $\mathrm{n}=15$, mean POD: $42.93 \pm 1.97$ days) and fourth samplings ( $\mathrm{n}=10$, mean POD: $64.3 \pm 1.14$ days) $(<31.3$ and $<4.7 \mathrm{pg} / \mathrm{ml}$, respectively).

Viral Load and Immune Responses in Hepatitis E

\section{Correlation between Cytokines and Outcome}

FHF-Fatal and Recovered

At Admission. There was no significant difference in rORF2p-induced Th1/Th2 cytokines levels in FHF recovered (mean POD, $7.5 \pm 1.1$ days) and fatal groups (mean POD, $13.17 \pm 1.42$ days) (table 2).

At the Time of Death/Recovery. In contrast to the insignificant difference at the time of first sampling, higher IFN- $\gamma$ and IL-12 levels were noted at last sampling in FHF recovered group as compared to fatal group ( $\mathrm{p}=$ 0.042 and 0.011 , respectively) (fig. 5). Due to the nonavailability of samples, TNF- $\alpha$ level could not be determined for repeat specimens.

Lymphocyte Proliferative Response to rORF2p

Of the $47 \mathrm{AVH}$ patients investigated, 31 could be subjected to the LPA. PBMCs of $7 / 31$ (22.58\%) of acute, $4 / 8$ $(50 \%)$ of FHF patients and $0 / 10$ controls responded to 


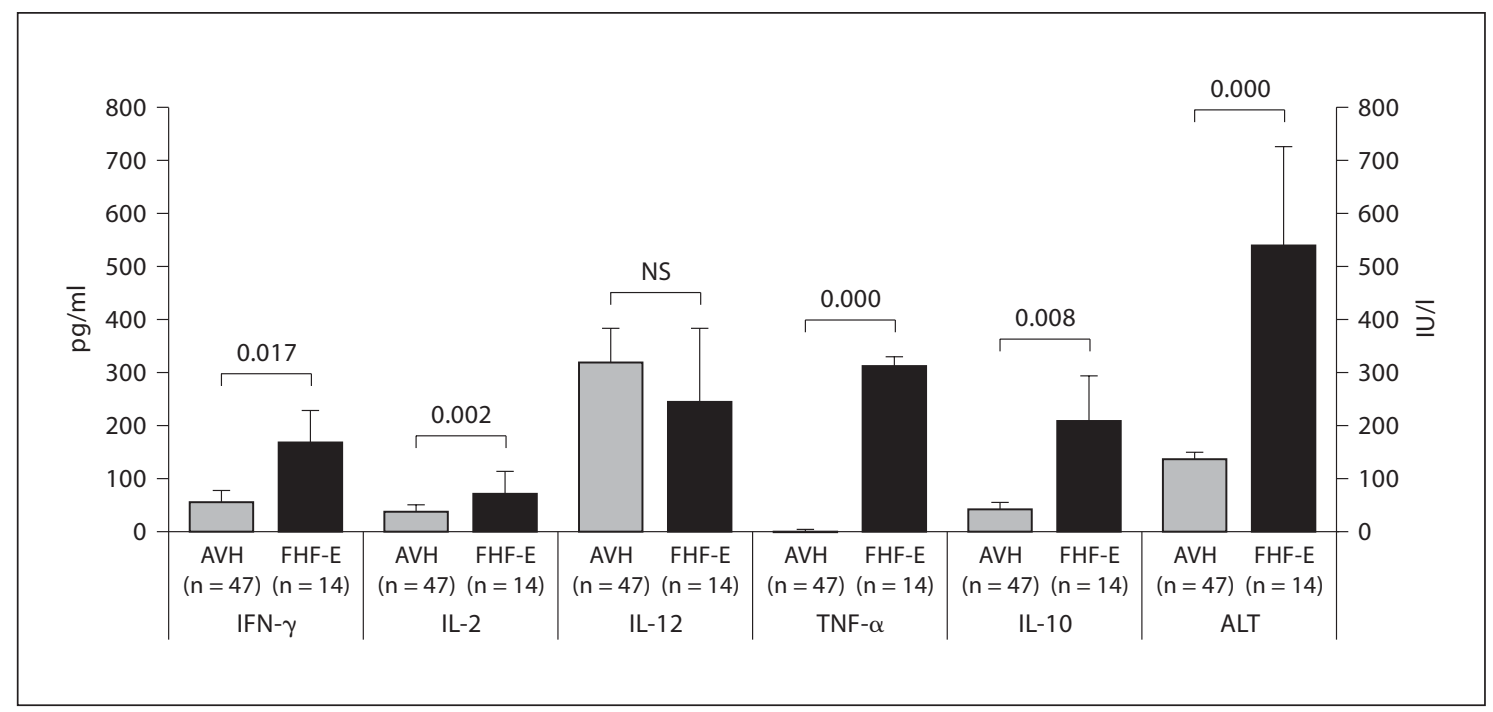

Fig. 3. Production of IFN- $\gamma$, IL-2, IL-12, TNF- $\alpha$ and IL-10 by PBMCs of AVH (mean POD, $12.84 \pm 1.99$ days) and FHF (mean POD, $9.93 \pm 1.57$ days) patients following stimulation with rORF2p along with ALT levels. Values indicate mean $\pm \mathrm{SE} \mathrm{pg} / \mathrm{ml}$ and IU/l. NS = Nonsignificant.

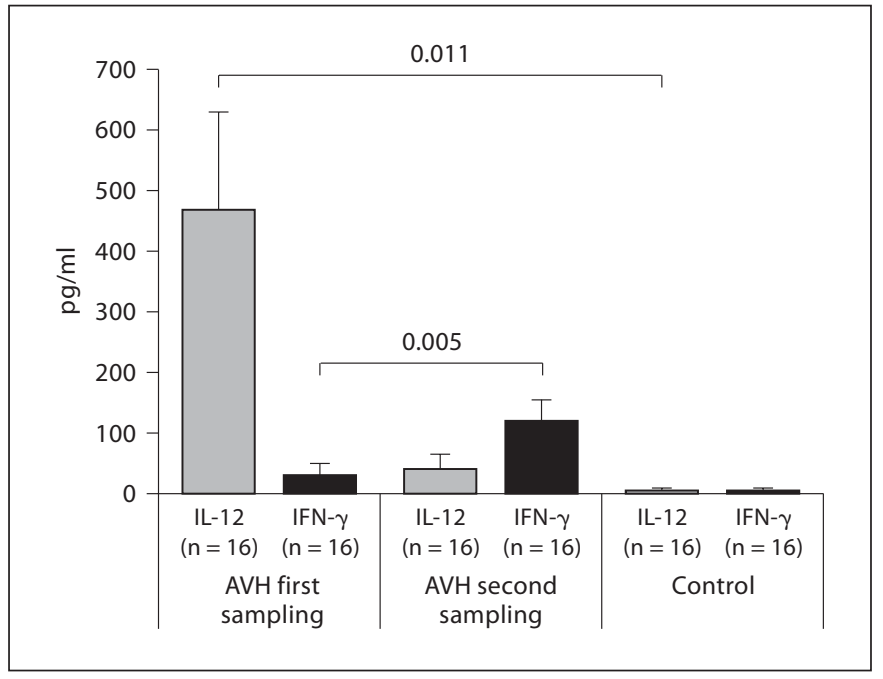

Fig. 4. Production of IFN- $\gamma$ and IL-12 in supernatants of rORF2p-stimulated PBMCs cultures from AVH patients and controls. Values indicate mean $\pm \mathrm{SE} \mathrm{pg} / \mathrm{ml}$. At the $3 \mathrm{rd}$ and 4 th samplings, these cytokines were below the detection limits and therefore not shown.

rORF2p. Among the responders, sequential samples were available for $3 \mathrm{FHF}$ and $3 \mathrm{AVH}$ patients and all responded till the last sample was collected 6-28 days after the initial sample. Lymphoproliferative response was recorded till the 48th POD for the AVH and the 12th



Fig. 5. Production of IFN- $\gamma$ and IL-12 by PBMCs from last samples of FHF recovered (POD, $13.57 \pm 1.30$ days) and fatal groups (POD, $16.50 \pm 1.42$ ). As given in table 2, there was no difference in these cytokines at the time of admission. Values indicate mean $\pm \mathrm{SE} \mathrm{pg} / \mathrm{ml}$.

POD for FHF, the last samples collected from these categories. The responders and nonresponders in both categories were compared with respect to IFN- $\gamma$ and IL-12 cytokines levels (fig. 6). However, no association was recorded. 




Fig. 6. Comparison of IFN- $\gamma$ and IL-12 levels among AVH and FHF patients showing lymphoproliferative response/no response. Values indicate mean $\pm \mathrm{SE} \mathrm{pg} / \mathrm{ml}$. NS = Nonsignificant.

Table 2. Production of cytokines from PBMCs of FHF recovered (POD, $7.5 \pm 1.1$ days) and fatal patients (POD, $13.17 \pm 1.42$ days) at the time of admission in response to $\mathrm{rORF} 2 \mathrm{p}$ antigen

\begin{tabular}{lcll}
\hline Cytokines & $\begin{array}{l}\text { FHF recovered } \\
(\mathrm{n}=8)\end{array}$ & $\begin{array}{l}\text { FHF fatal } \\
(\mathrm{n}=6)\end{array}$ & $\begin{array}{l}\mathrm{p} \\
\text { value }\end{array}$ \\
\hline IFN- $\gamma$ & $209.26 \pm 74.82$ & $100.22 \pm 91.35$ & $\mathrm{NS}$ \\
IL-2 & $35.19 \pm 15.45$ & $177.57 \pm 80.01$ & $\mathrm{NS}$ \\
IL-12 & $170.11 \pm 120.90$ & $444.19 \pm 144.19$ & $\mathrm{NS}$ \\
TNF- $\alpha$ & $364.24 \pm 19.84$ & $280.22 \pm 19.10$ & NS \\
IL-4 & $1.31 \pm 1.31$ & ND & NS \\
IL-10 & $148.88 \pm 96.66$ & $330.28 \pm 156.53$ & NS \\
\hline
\end{tabular}

ND = Not detected NS $=$ FHF recovered vs. fatal, not significant $(\mathrm{p}>0.05)$.

\section{Discussion}

This study confirms two of the earlier observations: high mortality in pregnant women, especially in the third trimester [3, 4], and HEV to be an important cause of FHF in non-pregnant women as well as men [18]. Overall mortality among FHF category was very high, i.e. $42.86 \%$.

In 1993, during a common-source outbreak of hepatitis $\mathrm{E}$ in Karad, the ratio of clinical:subclinical HEV infections among pregnant women was estimated by us to be
$1: 13$ and a substantial proportion of the subclinical infections were in the third trimester [19]. A crucial role of host immune response was envisaged. However, due to lack of a convenient cell-culture or animal model leading to large amounts of the virus of sufficient purity required for various immunological assays, such studies were hampered. Though rhesus monkey is an animal model for HEV, pregnant rhesus monkeys in the third para do not develop severe course of the disease [20]. Therefore, understanding the mechanism of the association of the pregnancy status with the severity of the disease cannot be studied in an animal model.

With the expression of the capsid protein (rORF2p) in the baculovirus expression system [17], a preliminary study was conducted during 2003-2006. Since all the FHF patients were admitted to a single unit of a medical college hospital, the treatment protocol was not responsible for differential outcome of FHF. An important observation was that when the patient developed FHF $\leq 2$ weeks of the development of jaundice, proportion of deaths $(3 / 11,27.3 \%)$ was less than those developing after 2 weeks (3/3). Thus, early development of FHF may indicate a better prognosis.

An unexpected observation of absence of HEV RNA in all but one FHF cases suggests that the extensive liver damage may not be associated with excessive replication of the virus. It was not possible to obtain liver biopsies, and therefore actual replication in the liver cells could not be ascertained. These results are in accordance with $\mathrm{Su}-$ zuki et al. [21] showing the absence of HEV RNA in 3 FHF patients. All HEV RNA positives investigated since 1981 belonged to genotype 1, and therefore the outcome was not related to infecting genotype (data not shown).

Irrespective of the outcome of the disease, the FHF patients bled within 2 weeks of onset of jaundice had significantly higher anti-HEV IgM and IgG titers. Subsequently, only IgM titers were higher. The role of overproduction of antibodies in the pathogenesis of FHF needs further investigations. A lack of correlation between the proliferative responses to HEV capsid protein and the presence of HEV-specific IgG in plasma was observed. Lymphoproliferative response to rORF2p was not different in AVH or FHF cases; T cell epitopes on rORF2p were recognized by both patient categories.

Comparison of Th1 and Th2 cytokine levels led to some interesting findings. Earlier, we had used plasma samples for the estimation of cytokine levels during different stages of acute-resolved hepatitis E. However, in plasma the levels remain below the detection limits of the assay. This was in sharp contrast to the observations with 
hepatitis A [22]. As a result, we measured the cytokine levels from the supernatants of PBMCs stimulated with HEV-specific recombinant antigen. In AVH, only IL-12 (Th1) levels were elevated when compared to controls. In contrast, significantly higher levels of both Th1 (IFN- $\gamma$, IL-2 and TNF- $\alpha$ ) and Th2 (IL-10) cytokines were present in FHF patients when compared with the AVH category (fig. 3). The concomitant significant rise in serum ALT levels in FHF patients indicating degree of liver damage suggests probable role of these cytokines in pathogenesis of HEV infection. A substantial increase in IL-10 production along with the higher levels of Th1 cytokines in FHF patients indicates involvement of anti-inflammatory response. It is likely that during FHF, IL-10 was released to limit inflammatory response probably induced by IFN$\gamma$, IL- 2 and TNF- $\alpha$. Thus, both inflammatory and antiinflammatory reactions were present in FHF patients.

To understand the association of these cytokines with the outcome of FHF, fatal and recovered groups were compared. At the time of admission, no significant difference was recorded. However, during the later stages of the disease, IFN- $\gamma$ and IL-12 levels were significantly higher in recovered than fatal patients strongly suggesting an important role of these cytokines in modulating severe course of the disease. We need to investigate these cytokines/related mechanisms in FHF patients during subsequent studies.

We further compared IFN- $\gamma$ and IL-12 cytokine levels between both categories of the patients with respect to lymphoproliferative response. No significant correlation was recorded suggesting that $\mathrm{T}$ cell activation, as assessed by LPA, may not be playing a key role.

An observation of IL-12 administration in pulmonary model of Cryptococcus leading to increased IFN- $\gamma$ levels deserves mention here [23]. In hepatitis E, an initial rise in IL-12 levels resulting in increased IFN- $\gamma$ levels in the later samples may be a distinct possibility. Analyses of sequential samples in AVH patients (fig. 4) documented the involvement of IL-12 in inducing IFN- $\gamma$ at a later stage probably leading to recovery. It seems that patients responding with an increased IL-12 production will promote Th1 development and stimulate the production of IFN- $\gamma$. Absence of IL-12 in FHF fatal cases strongly indicates that this cytokine may be instrumental in recovery. A detailed analysis of the roles of IL-12 and IFN- $\gamma$ in the pathogenesis of hepatitis E must be taken up on priority in countries with high disease endemicity.

In conclusion, the results demonstrate the role of cytokines in self-limiting as well as fulminant hepatitis $\mathrm{E}$ and emphasize the need for in-depth immunological studies.

\section{Acknowledgements}

The authors thank the Director, NIV, for all the support and are grateful to the staff of the Department of Medicine, BJ Medical College for all the help in getting the clinical samples. Thanks are due to Prakash Jawalkar, Bipin Tilekar, Vasant Walkoli, Dr. Tejaswini Deshmukh and Shirish Vaidya for all the help and Atul Walimbe for statistical analysis.

\section{References}

1 Arankalle VA, Chadha MS, Tsarev SA, Emerson SU, Risbud AR, Banerjee K, Purcell $\mathrm{RH}$ : Seroepidemiology of water-borne hepatitis in India and evidence for a third enterically-transmitted hepatitis agent. Proc Natl Acad Sci USA 1994;91:3428-3432.

$\checkmark 2$ Arankalle VA, Chobe LP, Jha J, Chadha MS, Banerjee K, Favorov MO, Kalinina T, Fields $\mathrm{H}$ : Aetiology of acute sporadic non-A, non-B viral hepatitis in India. J Med Virol 1993;40: 121-125.

>3 Khuroo MS, Teli MR, Skidmore S, Sofi MA, Khuroo MI: Incidence and severity of viral hepatitis in pregnancy. Am J Med 1981;70: 252-255.

4 Chadha MS, Mehendale M, Arankalle VA, Athalye K, Banerjee K: Water supply schemes and enteric transmitted non-A non-B hepatitis epidemics: an experience in Khadakwasla village of Pune district. Ind J Comm Med 1991; 16:153-158.
5 Arankalle VA, Jha J, Favorov MO, Chaudhari A, Fields HA, Banerjee K: Contribution of $\mathrm{HEV}$ and $\mathrm{HCV}$ in causing fulminant nonA, non-B hepatitis in western India. J Viral Hepat 1995;2:189-193.

6 Khuroo MS, Kamili S: Aetiology and clinical course and outcome of sporadic acute viral hepatitis in pregnancy. J Viral Hepat 2003; 10:61-69.

$\checkmark 7$ Acharya SK, Dasarathy S, Kumar TL, Sushma S, Uma Prasanna KS, Tandon A, Sreenivas V, Nijhawan S, Panda SK, Nanda SK, Irshad M, Joshi YK, Duttagupta S, Tandon RK, Tandon BN: Fulminant hepatitis in a tropical population: Clinical course, cause, and early predictors of outcome. Hepatology 1996;23: 1448-1455.

-8 Bernuau J, Rueff B, Benhamou JP: Fulminant and subfulminant liver failure: definitions and causes. Semin Liver Dis 1986;6: 97-106.
-9 Ostapowicz G, Fontana RJ, Schiødt FV, Larson A, Davern TJ, Han SH, McCashland TM, Shakil AO, Hay JE, Hynan L, Crippin JS, Blei AT, Samuel G, Reisch J, Lee WM: Results of a prospective study of acute liver failure at 17 tertiary care centers in the United States. Ann Intern Med 2002;137:947-954.

10 Bernal W: Changing patterns of causation and the use of transplantation in the United Kingdom. Semin Liver Dis 2003;23:227237.

11 Trey C, Davidson CS: The management of fulminant hepatic failure. Prog Liver Dis 1970;3:282-298.

12 Arankalle VA, Lole KS, Deshmukh TM, Chobe LP, Gandhe SS: Evaluation of human (genotype-1) and swine (genotype-4)-ORF2 based ELISAs for anti-HEV IgM and IgG detection in an endemic country and search for type-4 human HEV infections. J Viral Hepat 2007; 14:435-445. 
-13 Gandhe SS, Chadha MS, Walimbe AM, Arankalle VA: Hepatitis B virus: prevalence of precore/core promoter mutants in different clinical categories of Indian patients. J Viral Hepat 2003;10:367-382.

- 14 Bukh J, Purcell RH, Miller RH: Importance of primer selection for the detection of hepatitis C virus RNA with the polymerase chain reaction assay. Proc Natl Acad Sci USA 1992; 89:187-191.

-15 Arankalle VA, Lole KS, Deshmukh TM, Srivastava S, Shaligram US: Challenge studies in Rhesus monkeys immunized with candidate hepatitis E vaccines: DNA, DNAprime-protein-boost and DNA-protein encapsulated in liposomes. Vaccine 2009;27: 1032-1039.
6 Tripathy A, Balaji SS, Rao N, Thakare J, Mishra A, Arankalle VA: Cytokine levels in Chandipura virus associated encephalopathy in children. Scand J Infect Dis 2005;37: 590-593.

17 Deshmukh TM, Lole KS, Tripathy AS Arankalle VA: Immunogenicity of candidate hepatitis E virus DNA vaccine expressing complete and truncated ORF2 in mice. Vaccine 2007;25:4350-4360.

18 Chadha MS, Walimbe AM, Chobe LP, Arankalle VA: Comparison of etiology of sporadic acute and fulminant viral hepatitis in hospitalized patients in Pune, India during 1978-1981 and 1994-1997. Indian J Gastroenterol 2003;22:11-15.

19 Arankalle VA, Chadha MS, Dama BM, Tsarev SA, Purcell RH, Banerjee K: Role of immune serum globulins in pregnant women during an epidemic of hepatitis E. J Viral Hepat 1998;5:199-204.
20 Arankalle VA, Chadha MS, Banerjee K, Srinivasan MA, Chobe LP: Hepatitis E virus infection in pregnant rhesus monkeys. Indian J Med Res 1993;97:4-8.

-21 Suzuki K, Aikawa T, Okamoto H: Fulminant hepatitis E in Japan. N Engl J Med 2002;347: 1456.

22 Tripathy A, Chadha MS, Arankalle VA: Cytokine profiles in peripheral blood mononuclear cells and sera from patients with acute self-limited hepatitis A. Acta Virol 2005;49: 283-284.

23 Kawakami M, Tohyama M, Xie Q, Saito A: IL-12 protects mice against pulmonary and disseminated infection caused by Cryptococcus neoformans. Clin Exp Immunol 1996; 104:208-214. 